\title{
Analysis on WeChat Promotion Strategy of New Clothing Brand
}

\author{
Yang Yang \\ Jiangxi Institute of Fashion Technology \\ Nanchang, China 330201
}

\begin{abstract}
The clothing industry in China has had a fierce brand competition, of which the rule has great impact on the small and medium-sized clothing enterprises in brand creation. Enterprises begin to rely on the product quality and innovation instead of the advantage in scale and production cost. Compared with international clothing brands, the domestic clothing brands have vague positioning and lack in brand culture, which will reduce the recognition of customers in the brand promotion, produce the distance between the brand and the customers and make the cost of brand promotion far beyond the budget. This paper concludes the theories of brand building and analyzes the differences between new brand and famous brand, and then further analyzes how to use WeChat to avoid planning risk and make a low-cost and high-efficiency promotion of the new brands with low cognition, so it has reference value for promotion of new brands in clothing enterprises.
\end{abstract}

Keywords-WeChat promotion; newly created; culture; new media

\section{INTRODUCTION}

With the rapid development of economy in China, the clothing enterprises have begun the brand building. The participants of brand building cover the customers, the channel operation, the cooperative clients and the competitors. The brand building also contains many contents, like the positioning, promotion and marketing of the brand. The main purpose of brand building is to let the image and the culture of clothing enterprises enjoy popular support of the target customers, and further to improve the value of enterprises.

\section{PROBlEMS IN PROMOTION OF NEWLY CREATED BRANDS}

\section{A. The New Brands Have Low Cognition Degree Because of No Obvious Brand Features}

The low cognition degree of the brand shows the low competitiveness of clothing enterprises. The brand awareness represents the competitiveness of clothing industry. In today's consumption market, no big differences exist in products and the service provided by competitive clothing enterprises. Customers will purchase according to brand awareness. Newly created brands lack the popularity. Customers' choice often depends on the superiority of products or the price, like personalized design or lower price. However, it is adverse to the newly created brands. With low popularity, the brand cannot attract customers, who will not be willing to know about the connotation and individuality of the brand only by product innovation. The difference of the newly created brands should reflect on products as well as brand image.

\section{B. The Newly Created Brands Lack the Cost Advantage}

When the brands are created at first, clothing enterprises must bear the cost and use various methods to improve the popularity and image of the enterprise and the product in a certain area. Currently, more and more clothing enterprises are trying to occupy the market, which can lower the cost and reduce the risk of enterprises in operation. It is very difficult for newly created brands to surpass the brands with higher popularity. The invested cost cannot be in direct proportion to the return, which is the biggest problem in the promotion of newly created brands.

\section{The Newly Created Brands Have Little Information Feedback, Lacking Interaction with the Customers}

The efficiency of promotion reflects in the information feedbacks of customers. The traditional clothing enterprises often use one-to-many one-way form to carry out the brand promotion, like advertisements, magazines and news letters. It is difficult to get information feedback without clear object customers.

\section{WeChat Promotion STRATEGy FOR THE NEWLY CREATED CLOTHING BRANDS}

\section{A. Enhance the Brand Awareness through Multiple Channels and Ways}

The WeChat promotion strategy is a burgeoning new media promotion mode at present. Compared with the promotion of traditional media, the WeChat promotion integrates all the promotion resources and the development, design, channel, marketing and promotion, popularization and service through the interaction between the virtuality and the reality. The main function of $\mathrm{WeChat}$ is to maintain the relations between people and form a group having strong oneto-one two-way mode and accurate acceptance rate. Compared with other social media, the biggest advantage of WeChat in promotion is the trueness of the users' information, improving the accuracy and convenience of propagation. It removes the offline relationship of the group to the online platform, so that the users can choose the social groups independently. 
The official account is an important service in the WeChat. According to the investigation, more than four fifths of WeChat users pay attention to the official accounts related to enterprise promotion and we media. The WeChat public platform passes on information to the users mainly through the official accounts. The information bases on the users' choice instead of the viral marketing of internet. Users actively acquire the information, forming the relational communication. The WeChat public platform can be more diversified, concrete and systematic in promotion, but the number of information is limited. In the WeChat platform, for the newly created brand, the positioning of the brand and the price can be decided flexibly, free from the limitation of brand image.

\section{B. Low Cost and High Return}

According to the costs of advertising on websites and media, compared with the cost invested on traditional websites of media transmission like the web portals and the fashion websites, the cost of advertisement injecting on the client-side is very low. Besides, more targeted advertisement will further improve the propagation effect. Therefore, using WeChat to advertise the products can interact with the target customer continuously and save the cost in the brand promotion.

\section{Find out Target Customers Precisely to Realize Two-way Communication}

To further capture the target market, the new media must furthest meet the requirements of the target customers in the process of promotion and marketing. In the brand promotion, the traditional media often focus on the products, while the new media promotes according to the connotation and value of the brand. The propagation of WeChat turns from one circle of friends to another, from friends and acquaintance to strangers, contributing to closer relationships and more targeted contents of transmission. The unique values of the newly created brand can be spread through WeChat to attract target customers.

The WeChat can quantify the rate of return on investment and enable the customers to understand the connotation and culture of the brand. The creators can summarize the growth rate, regional distribution and male female ratio of people who pay attention to the official accounts and realize one-to-one precision marketing. Furthermore, the WeChat can provide integrated contents in the fragmented and distributed network information for customers to understand. Therefore, more and more newly created brands in China have begun to build the WeChat public platform to promote the brand culture and value and organize activities, so that the customers can participate in it and acknowledge the brand.

\section{Improve the Originality of Image and Text to Attract the Target Consumers}

The core of brand marketing is to "tell good stories". Find out the target customers, understand their requirements and create valuable brand stories to interact with them. The WeChat public platform can pass on the original contents to consumers with images and texts, so that consumers can be attracted and have new cognition on the brand. Moreover, the interaction can provide more contents and information for the target customer and create new stories. At present, some people adept in the WeChat official accounts deliver information about the fashion, life, psychology, consumption and entertainment closely related to the users' life demands. The individualized and emotional original contents are more popular among the users. Users can interact with others through replying messages or entering keywords. More requirements of the users can be collected through interaction, so that more unique stories will be created and more target customers will be influenced.

\section{E. Increase Interaction with Consumers on Wechat}

Compared with traditional promotion, the WeChat promotion has better interaction and communication to bring common and new information between the brand owner and customers and integrate the generation and output of the information. Although the WeChat has the function of information output like the official accounts, the social circle bases on the relation with classmates and friends. Therefore, the brand owners or operators cannot regard the WeChat as a platform to spread information but regard the brand can manage or promote the social circle instead of dominating.

Online activities and offline activities are combined on the WeChat platform for the brand, contributing to more rapid and all-around brand promotion and marketing. It involves the contents of event marketing, integrating the advertisement, sales promotion, public relation and promotion, establishing on the marketing of relational data. The mode and detailed rules of the activities are released on the WeChat platform for customers to experience offline with a sense of participation and presence. For newly created brands, brand owners should pay more attention to the activities planned for the brand instead of the product design, because the activities can attract more customers. For example, people can try out the products of the newly created cosmetics brand, Home Facial Pro through the public accounts and send their usage experience in the article. Customers can purchase the products for them to try directly through the links and purchase at a discount in the store according to the information shared by people on the official accounts.

\section{F. Improve the Loyalty of Customers through the Feedback of Profits}

The success of promotion strategy on the WeChat depends on the users' feedback. We should pay the most attention to the customers attracted initially, because they give not only the purchasing data but also confidence to the brand owner. The first consumer groups come from the circle of friends, so the WeChat promotion should mainly consider spreading through sharing. The feedback on the product or money can be carried out through the level of regular customers, which can improve the loyalty of regular customers as well as acquire more new customers.

\section{CONCLUSION}

The reason why the newly created brands choose the WeChat platform to market is that it can get close to the distance with target customers, improve the propagation path of the brands and then spread the brand image and value. 
Compared with the traditional promotion pattern, its propagation quality and speed are improved greatly. In the WeChat marketing and promotion, the popularity and influence of the brand and the customers' purchasing behaviors can be further improved. This paper mainly researches the WeChat promotion strategy for the newly created brands and explores whether the brand owner can accept the WeChat marketing. They still focus on the information conveyance function instead of the integration and promotion strategy of the brand. With the innovation of information technology, the promotion through WeChat platform will greatly improve the popularity of the brand and embody its benefit furthest.

\section{REFERENCES}

[1] Chen Siyu, Zhao Jun. Research on the WeChat Marketing Strategy for Clothing [J], Abstract: Economic Management, April 2015

[2] Li Wei. Brand Communication on New Media Based on the WeChat Take "Her Life" as an Example [J], News, June 2014.

[3] Zuo Peipei. Analysis on Problems in the WeChat Marketing [J], China Business and Trade, December 2013.

[4] http://epub.cnki.net/kns/popup/knetsearchNew.aspx?sdb=CMFD\&sfield $=\%$ e4\%bd $\% 9$ c $\%$ e $8 \% 80 \% 85 \&$ skey=\% e8\%83\%a1\% $6 \% 83 \%$ a0\% $7 \% 90$ $\%$ b4\&scode $=23230317 \% 3 \mathrm{~b}$ Yang Junchao. Research on the Influence of WeChat Marketing on Customers' Purchase Decision [D], Wuhan Textile University, March 2015.

[5] Niu Quanbao, Zhang Yan. The Research Status and Prospect of WeChat Marketing [J], Proceedings of the Tenth (2015) Chinese Management Academic Year, November 2015.

[6] Wang Liying. Discussion on the Advantages and Development Prospect of WeChat Marketing [J], Securities and Futures of China, October 2013. 